\title{
Nitrogen Fixation (Acetylene Reduction) Associated with Rhizosheaths of Indian Rice- grass used in Stabilization of the Slick Rock, Colorado Tailings Pile
}

\author{
L.H. WULLSTEIN
}

\begin{abstract}
Indian ricegrass sown on a sandy soil covering a uranium mine tailings exhibited associative nitrogen fixation (acetylene reduction). Acetylene reduction rates for whole plants varied from 2,100 to $19,500 \mathrm{~nm} / 4$ days. Nitrogen fixation was associated with the rhizosheaths. It is suggested that the reclamation of mine tailings in arid climates may be facilitated by stabilizing sandy textured coverings with rhizosheath-forming grasses.
\end{abstract}

Nitrogen fixation has been reported to be associated with rhizosheaths of Indian ricegrass, Oryzopsis hymenoides, on sandy sites under conditions of moisture and nitrogen stress (Wullstein et al. 1978).

During March, 1971, the Union Carbide Corporation (Beverly 1978) covered a uranium tailings pile, near Slick Rock, Colorado, with a loamy sand (Ludwick 1971). This covering was sown with a seed mixture including Indian ricegrass during October, 1973 (Beverly 1978). The seeding was relatively successful with respect to the Indian ricegrass only (Fig. 1). Examination of the roots in August, 1978, indicated general rhizosheath formation (Fig. 2). This report presents data indicating nitrogen fixation (acetylene reduction) is specifically associated with these rhizosheaths.

\section{Area and Methods}

The tailings pile, comprising about 7 ha, was covered to a depth of $15 \mathrm{~cm}$ to $20 \mathrm{~cm}$ with the loamy sand (Union Carbide Corp. 1971, and personal communication, Mr. R.G. Beverly). Soil test results of the cover material are given in Table 1 (Ludwick 1971). Fertilizers were applied with a spreader just prior to seeding. Approximately $242 \mathrm{~kg}$ of ammonium nitrate and $182 \mathrm{~kg}$ of triple super phosphate were applied per hectare (Union Carbide Corp. 1973). Seeding was done by drilling at a rate of $19 \mathrm{~kg}$ of mixed seed including $6 \mathrm{~kg}$ of Indian ricegrass seed per hectare (Beverly 1978). Although the site is an arid one, no water has ever been applied nor has there been any subsequent nitrogen fertilization (Beverly 1978).

During August, 1978, whole plants of Indian ricegrass were collected and tested for acetylene reduction (Stewart et al. 1967). Within 24 hours after collection, the plant roots, including rhizosheaths, were placed in plastic bags and covered with the sandy loam (Wullstein et al. 1978). The bags were then sealed at the root crown, air and acetylene injected (Wullstein et al. 1978), and

\footnotetext{
Author is biologist, Department of Biology, University of Utah, Salt Lake City, 84112

Grateful acknowledgement is made to the Bureau of Mines, U.S. Department of Interior, for their cooperation. Mr. R.G. Beverly, Union of Carbide Corporation, is acknowledged for providing the background information on the stabilization of the Slick Rock tailings and reviewing the manuscript. The photographs were taken and developed by Mr. Richard Young, Department of Biology, University of Utah.

Manuscript received January 8, 1979
}

incubation carried out under ambient greenhouse conditions. Previous experiments (unpublished) have shown the nitrogen fixers associated with these specimens are anaerobic or microaerophillic. It is thought that microaerophillic conditions can obtain within the rhizosheath under aerobic atmospheres (Wullstein et al. 1978).

In order to demonstrate that nitrogen fixation is associated with the rhizosheaths, test samples were prepared by removing individual sand grains in a manner to generally exclude roots (Wullstein et al. 1978). Samples of these grains were then assayed for acetylene reduction in $100 \mathrm{ml}$, stoppered serum bottles under anaerobic conditions (Wullstein et al. 1978). Incubations were carried out in the dark at $25^{\circ} \pm 1^{\circ} \mathrm{C}$. Total nitrogen analyses (Nelson and Sommers 1973) were made on grass, tailings, and cover samples also collected in August, 1978. In addition aqueous extracts of the tailings and cover sand were analyzed for mineral nitrogen (AOAC 1970).

\section{Results and Discussion}

Table 2 shows that the acetylene reduction rates for the whole plants range from 2,100 to $19,500 \mathrm{~nm} \mathrm{C}_{2} \mathrm{H}_{4} / 4$ days. The mean rate was $8,469 \mathrm{~nm} \mathrm{C}_{2} \mathrm{H}_{4} / 4$ days. Variable results such as these have been noted to be associated with acetylene reduction assays (Knowles and O'Toole 1975) and may reflect, in part, variability attributable to sampling (see discussion below). Nevertheless, if these rates, obtained for August specimens, are representative of field rates significant quantities of nitrogen would be expected to be fixed. For example, the mean rate of $8,469 \mathrm{~nm} \mathrm{C}_{2} \mathrm{H}_{4} / 4$ days/plant is equivalent to ca $20 \mu \mathrm{g} \mathrm{N} /$ day/plant. However, it is recognized that experimental limitations generally preclude the exact extrapolation of acetylene reduction rates to nitrogen fixation (Bergersen 1970). Dry weights of the August specimens varied from about 17 to $28 \mathrm{gm}$. However, no correlation was found between these dry weights and the acetylene reduction rates, the amounts of total plant nitrogen recovered, (Tables 2,4$)$. This suggests a need for obtaining acetylene reduction rates, and corresponding dry weights during the course of the entire growing season. In contrast to these rates for a xeric species, Tjepkema and Evans (1976) reported much higher values for wetland plants.

The data in Table 3 attest to a specific relationship between nitrogen fixation activity and the rhizosheaths (Wullstein et al. 1978). These greatly reduced rates $(\bar{X}=$ 66.6), compared to those obtained for the whole plants, may be attributed to the general disruption of the sheath structure. This would be expected to reduce carbon and nutrient availability to associated nitrogen fixers. Also, lower rates could have resulted from the exposure of microaerophillic 
Table 1. Soil test results for tailings pile cover.

\begin{tabular}{|c|c|c|c|c|c|c|c|c|c|}
\hline $\begin{array}{l}\mathrm{pH} \\
\text { paste }\end{array}$ & $\begin{array}{l}\text { Cond. (Salts) } \\
\text { mmohs } / \mathrm{cm}\end{array}$ & Lime & $\begin{array}{l}\text { Organic } \\
\text { matter } \%\end{array}$ & $\begin{array}{c}\text { Phosphorus } \\
\text { ppm P }\end{array}$ & $\begin{array}{l}\text { Potash } \\
\text { ppm K }\end{array}$ & Texture & $\begin{array}{c}\mathrm{NO}_{3}-\mathrm{N} \\
\text { ppm }\end{array}$ & $\begin{array}{c}\mathrm{Zn} \\
\mathrm{ppm}\end{array}$ & $\begin{array}{c}\mathrm{Fe} \\
\mathrm{ppm}\end{array}$ \\
\hline 8.0 & 3.0 & High & 0.5 & 2.5 & 140 & $\begin{array}{c}\text { Loamy } \\
\text { Sand }\end{array}$ & 1.1 & 0.36 & 4.6 \\
\hline
\end{tabular}

Table 2. Acetylene reduction associated with whole plants of Indian ricegrass.*

\begin{tabular}{cc}
\hline \hline Sample No. & $\mathrm{nm} \mathrm{C}_{2} \mathrm{H}_{4} / 4$ days \\
\hline 1 & 2,100 \\
2 & 3,700 \\
3 & 6,700 \\
4 & 7,350 \\
5 & 8,200 \\
6 & 9,800 \\
7 & 10,400 \\
8 & 19,500 \\
& $\bar{X}=8,469 \pm 5,277$ (S.D.)
\end{tabular}

* Control values substracted. Controls were similarly prepared with tailings cover sand ( $500 \mathrm{gm})$ obtained from nonvegetated interspaces.

nitrogen fixers to air during sample preparation (Tjepkema and Evans 1976). Sample incubation, prior to acetylene injection, was not done in any of the experiments reported here since this practice may lead to overestimates of nitrogen fixation activity (Barber et al. 1976). It remains to be shown
Table 3. Acetylene reduction associated with disintegrated rhizosheath samples.*

\begin{tabular}{cc}
\hline \hline Sample No. & $\mathrm{nm} \mathrm{C}_{2} \mathrm{H}_{4} / 10 \mathrm{gm} / 24 \mathrm{hrs}$ \\
\hline 1 & 85 \\
2 & 105 \\
3 & 39 \\
4 & 48 \\
5 & 58 \\
6 & 66 \\
7 & 40 \\
8 & 83 \\
& $\bar{X}=67 \pm 23(\mathrm{~S} . \mathrm{D})$
\end{tabular}

*Control values substracted. Controls were similarly prepared with tailings cover sand $(10 \mathrm{gm})$ obtained from nonvegetated interspaces.

if nitrogen fixed in the rhizosheaths is assimilated by the plant (Wullstein et al. 1978).

Sufficient nitrogen does not appear to have been available in the sandy covering (Table 1) or from the added amonium

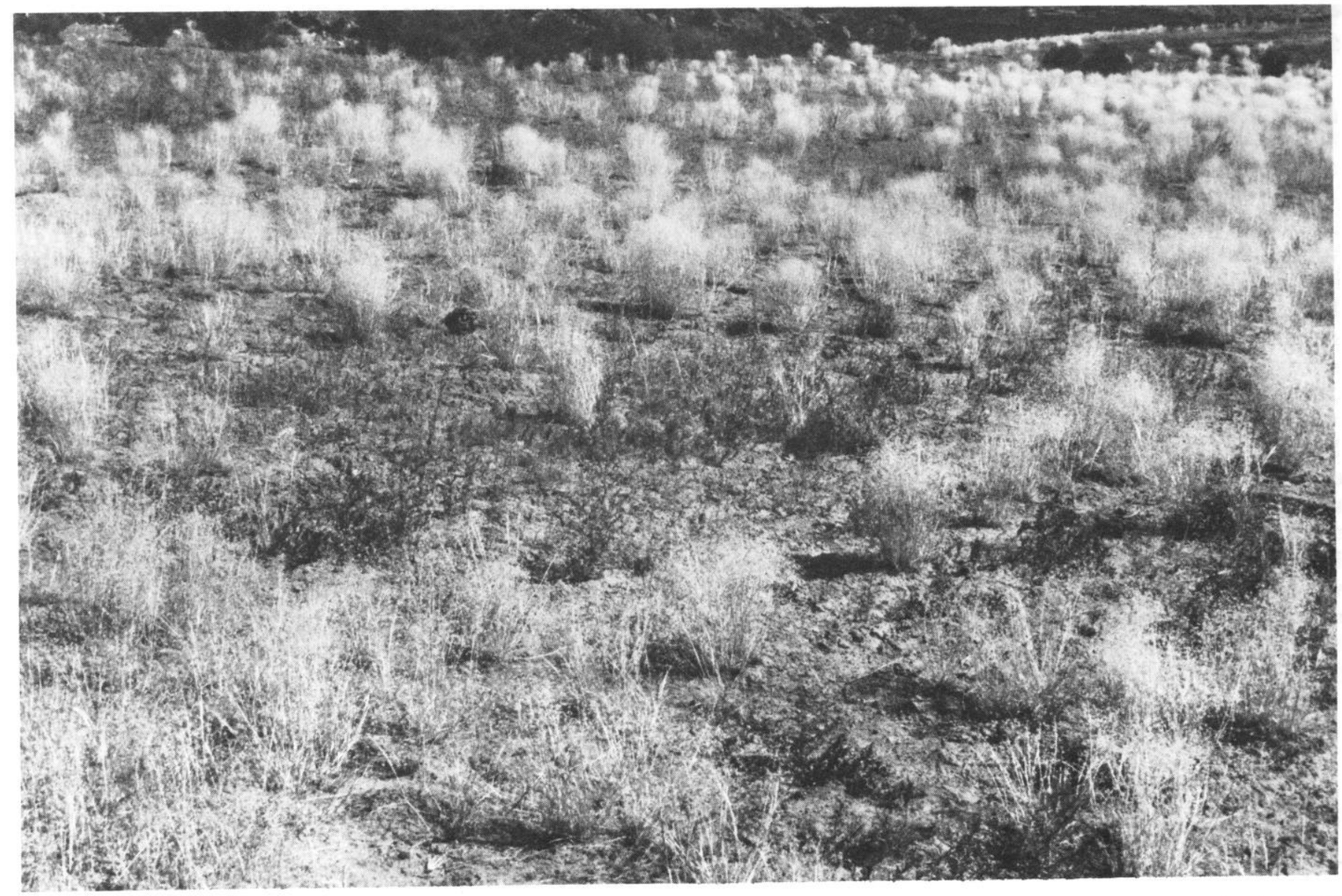

Fig. 1. General view of the Slick Rock tailings site. The predominant bunchgrass is Indian ricegrass seeded on the sandy loam covering, October, 1973. 


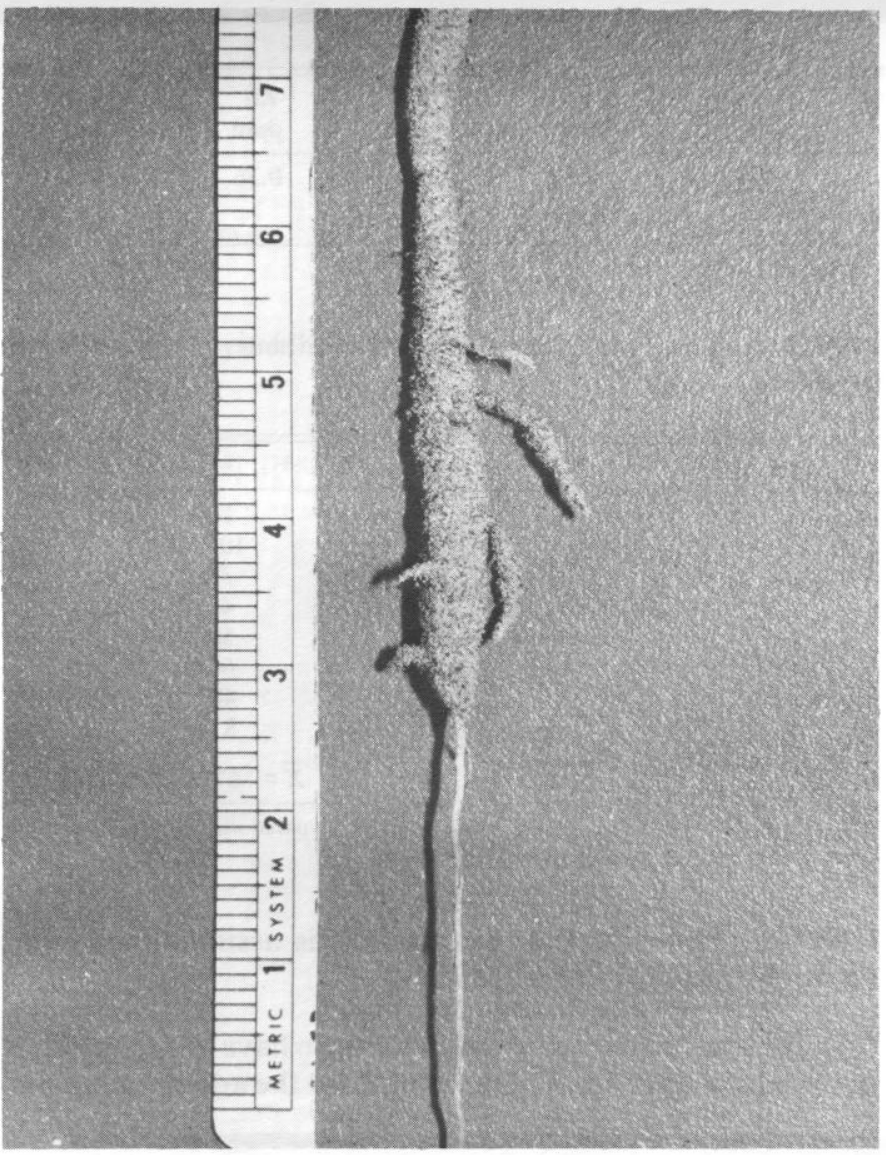

Fig. 2. Well-developed rhizosheath on root of Indian ricegrass seeded on the Slick Rock tailings cover.

nitrate (ca $85 \mathrm{~kg} \mathrm{~N} /$ ha) to account for the total nitrogen recovered $(X=27.2 \mathrm{mg} / \mathrm{gm})$ from the grass samples (Table 4). Analysis of nonvegetated samples of the cover material showed only trace amounts of total nitrogen to less than 5 ppm mineral nitrogen. Field observations have demonstrated that Indian ricegrass roots can penetrate the underlying tailings, and might, thereby, obtain available nitrogen. However, mineral and total nitrogen analyses of tailings samples revealed the presence of only trace amounts of nitrogen. The area has been fenced, but occasionally some cattle have entered, and, no doubt, have added some limited amounts of excretory nitrogen (personal communication, Mr. R.G. Beverly). From these considerations it appears the deficit between total plant nitrogen and known available nitrogen is real. Thus, nitrogen fixation in the rhizosheaths may be more significant than indicated by the August rates. It seems likely, for example, that nitrogen fixation activity would be much greater early in the growing season when more carbon, nutrients, and moisture would be expected to be available to the nitrogen fixers within the rhizosheaths (Wullstein 1978). Moreover, sample preparation may have
Table 4. Total nitrogen determinations, Indian ricegrass.*

\begin{tabular}{cc}
\hline \hline Plant No. & $\mathrm{mg} /$ gm (dry wgt.) \\
\hline 1 & 29.6 \\
2 & 27.5 \\
3 & 23.8 \\
4 & 31.1 \\
5 & 24.4 \\
6 & 30.2 \\
7 & 26.9 \\
8 & 26.3 \\
9 & 24.7 \\
& $\bar{X}=27.2 \pm 2.6$ (S.D.)
\end{tabular}

*Values are means of duplicate analyses made on combined root and shot samples per plant.

inhibited the nitrogen fixers in the whole plant assays as suggested previously for the rhizosheath assays.

This study suggests the reclamation of tailings piles in arid climates may be facilitated where sandy textured coverings are used, and stabilized with rhizosheath-forming grasses. This practice appears to have the potential for minimizing the need for water and nitrogen applications. Additional field trials are recommended to test this possibility.

\section{Literature Cited}

Association of Official Analytical Chemists. 1970. Official methods of analysis. W. Horwitz (Ed.). Ass. Offic. Anal. Chem., Washington, D.C. $1,015 \mathrm{p}$.

Barber, L.E., J.D. Tjepkema, S.A. Russell, and H.J. Evans. 1976. Acetylene reduction (Nitrogen Fixation) associated with corn inoculated with Spirillum. Appl. and Environ. Microbiol. 32: 108-113.

Bergerson, F.J. 1970. The quantitative relationship between nitrogen fixation and the acetylene reduction assay. Aust. J. Biol. Sci. 23: 10151025.

Beverly, R.G. 1978. In letter, dated August 24, from R.G. Beverly (Union Carbide Corporation) to L.H. Wullstein.

Knowles, R., and P. O'Toole. 1975. Acetylene reduction assay at ambient $\mathrm{PO}^{2}$ of field and forest soils: laboratory and field core studies. p. 285-294. In: W.D.P. Stewart (Ed.), Nitrogen Fixation by Free-Living Microorganisms. Cambridge University Press, Cambridge.

Ludwick, A.E. 1971. Soil test results and plant nutrient recommendations. Coop. Ext. Serv. and Exp. Sta., Colo. State Univ. Rep. to Union Carbide Corporation.

Nelson, D.W., and L.E. Sommers. 1973. Determination of total nitrogen in plant material. Agron. J. 65: 109-112.

Stewart, W.D.P., G.P. Fitzgerald, and R.H. Burris. 1967. In situ studies on $\mathrm{N}_{2}$ fixation using the acetylene reduction technique. Proc. Nat. Acad. Sci., USA 58: 2071-2078.

Tjepkema, J.D., and H.J. Evans. 1976. Nitrogen fixation associated with Juncus balticus and other plants of Oregon wetlands. Soil Biol. Biochem. 8: 505-509.

Union Carbide Corporation. 1971. Specifications for tailings pile stabilization at Slick Rock, Colorado. Specifications No. 935-1901. 5 p.

Union Carbide Corporation. 1973. Specifications for fertilizing and seeding Slick Rock tailings pile, Slick Rock, Colorado. Specifications No. 935-3116. 3 p.

Wullstein, L.H., and M.L. Bruening, and W.B. Bollen. 1979. Nitrogen fixation associated with rhizosheaths of certain perennial grasses. Phys. Plant. 46: 1-4. 